\title{
Performance of Commission Recipient: Impact of Discipline, Motivation, Training and Incentive
}

\author{
Deden Tarmidi ${ }^{1} \quad$ Yvonne Augustine ${ }^{2}$ \\ 1.Faculty of Economic and Business, Universitas Mercu Buana, \\ Jl. Meruya Selatan No. 1, Kembangan, Jakarta Barat 11650 \\ 2.Faculty of Economic and Business, Universitas Trisakti, \\ Jl. Kyai Tapa No. 1, Grogol, Jakarta Barat 11440
}

\begin{abstract}
This study aims to determine the impact of discipline, motivation, training and incentives on the performance of commission recipient drivers. As knew that Human Resources have an important role for the sustainability of the company, including the driver as a marketing in the transportation companies. Adopted some prior research for measurement of variables and hypothesis development such as Al-Belushi and Khan (2017), Pawirosumarto et al. (2017), Nabi et al. (2017), and Khan et al. (2014), Salem and Abdien (2017), Sharma (2016), Groen et al. (2016), Kumara and Utama (2016), Hatane (2015), Falola et al. (2014), Kuzu and Ozilhan (2014), Hameed et al. (2014), Bhat (2013) e-questionnaire developed and with snowballing method collected 94 data's from taxi driver as the respondent. The results showed that discipline and motivation have a positive impact on performance significantly but training and incentive as a company policy to tax driver are not. These result is great information for the transportation companies to be applied to the driver's recruitment and managing the policy of the driver.
\end{abstract}

Keywords: Performance, Discipline, Motivation, Training, Incentive

DOI: $10.7176 / J R D M / 52-06$

\section{Introduction}

Human Resources have an important role for the sustainability of the company, both as internal employee and non-employee who deal with company activities directly or not, from top management to the lowest level (Hatane, 2015; Vosloban, 2012). Because each person has different characteristics, the performance in work will be different as well as their perceptions of what they receive during work. In some previous studies, discipline and motivation that employees have has a positive impact on employee performance (Mullen et al., 2017, Groen et al., 2016; Gellert and Schalk, 2012; Pawirosumarto, 2017) as well as training and incentives received by employees have a positive impact on employee performance (Kumara and Utama, 2016; Bhat, 2013; Khan et al., 2014; Hameed et al. 2014; Triasmoko et al., 2014).

In transportation companies in Indonesia especially taxi, the incentive system consists of several types, namely the salary system and the commission system. In the payroll system, the driver is paid every month and does not depend on the turnover generated so the driver feels safe when working as an office worker in general. While on the commission system, the driver is paid based on the turnover generated so that the amount of income received depends on the driver's performance when working. The performance analysis of the recipients of the taxi driver in particular is unique and novelty of this research. The contribution of this study can provide input to companies, especially in the field of transportation to improve driver performance.

Taxi companies are service companies whose turnover depends on customer satisfaction, the driver taxi service especially on passenger safety (Mullen et al., 2017) and service quality (Gellert and Schalk, 2012) then it becomes a benchmark for the sustainability of the company. Based on this background, this study aims to determine the impact of discipline, motivation, training and incentives on the performance of commission recipient drivers.

\section{Literature Review}

2.1 Theoretical Framework

2.1.1. Social Psychology of Organization

McGregor in the theory of X explains that company leaders arrange employees to work according to company rules to achieve organizational goals. In line with the rules assigned to employees, employee rights are also regulated to improve the quality of work of employees. Training and incentives are part of company policies that are applied to employees.

In addition, McGregor in Y theory also explains that employees are given the authority to work in their own way to achieve organizational goals. Because of this authority, employees will determine for themselves how to achieve organizational goals. Then the individual factors of employees will determine what and how the views and ways of working each individual to produce the expected performance. Discipline and motivation is one of the individual factors that in many studies have known to have an influence on individual performance. 


\subsubsection{Locus of Control}

Rotter (1966) which triggers the theory of locus of control explains that a person has their own control over themselves about the job there is influence from both external and from himself. In the performance of taxi drivers, especially with the commission system, individual belief and control factors are the determinants of the success or failure of the work carried out according to the organization's goals.

When the driver individually believes that he is able to control himself with discipline and personal motivation or from company policies such as training and incentives, then that belief will be reflected in his performance in driving.

\subsubsection{Performance}

Performance is the result of individual or group job in accordance with their respective functions and duties (Gilbert, 1977; Wibowo, 2016). This study focuses on analyzing the performance of taxi drivers in serving passengers. The performance of taxi drivers is an important factor in the development of taxi companies because as other service companies that service to consumers is the spearhead in increasing revenue now and also in the future. Current customer satisfaction with driver service will provide a positive image of the company and of course the increased use of taxi transportation services.

\subsection{Conceptual Framework and Hypothesis Development}

Differences in the characteristics of employee internal factors certainly have a different impact on the performance of employees themselves. as well as company policies to employees directly or indirectly impact on employees and performance in the end.

\subsubsection{Impact of Discipline on Performance}

Discipline is a form of obedience to rules. Work discipline is always a reference for every employee in determining the success or failure of the assignment given. According to Rivai and Sagala (2009), work discipline is a tool for communicating to employees that is used by managers so that employees are willing to comply with all applicable rules and norms. Pawirosumarto et al., (2017) found results that the discipline possessed by individuals had a positive impact on performance, so the hypothesis of this study is:

\section{H1. Discipline has a positive impact on Performance}

2.2.1 Impact of Motivation on Performance

Hezberg (1964) explained the motivation theory that someone does a job because it has two motivations, namely job satisfaction and job dissatisfaction, when a person feels satisfied with his job then he will feel comfortable doing the work and vice versa if someone is not satisfied with the job then the job will be left.

While Vrom (1964) in the theory of expectation explains that someone does a job because it has certain motivations both positively and negatively. So that motivation will encourage individuals to do a job, satisfied or dissatisfied. In this study, the motivation of each driver is expected to encourage him to work so that it has a good impact on their respective performance. Al-Belushi and Khan (2017), Pawirosumarto et al. (2017), Nabi et al. (2017), and Khan et al. (2014) found results that motivation had a positive impact on performance, so the hypothesis of this study is:

\section{H2. Motivation has a positive impact on Performance}

\subsubsection{Impact of Training on Performance}

Training is an introductory activity, teaches to train individuals in carrying out things, in this study the company provides training to drivers at the beginning of the working period to introduce driving methods and good services and other rules and at certain times to update the latest provisions and deepen knowledge and skills in driving and service to passengers. Salem and Abdien (2017), Sharma (2016), Kumara and Utama (2016), Falola et al. (2014), Bhat (2013) in their study found results that training had a positive effect on individual performance. Based on this, the hypothesis of this study are:

\section{H3. Training has a positive impact on Performance}

\subsubsection{Impact of Incentive on Performance}

Incentives are other benefits of salaries received by employees, the form can be in the form of bonuses or other facilities. But for drivers who work with the commission system, incentives are all things that individuals receive and enjoy in the form of commissions, bonuses and other benefits. Al-Belushi and Khan (2017), Groen et al. (2016), Hameed et al. (2014) in their study found results that incentive had a positive effect on individual performance. Based on this, the hypothesis of this study are:

\section{H4. Incentive have a positive impact on Performance}

\section{Methodology}

3.1 Population and Sample

Taxi blue bird drivers in the Jakarta Indonesia area were used as the unit of analysis in this study, with a population of 23,000 in 2018 (www.bluebirdgroup.com), convenience sampling and snowballing methods were conducted to obtain research data. The link of the e-questionnaire with the linkert scale 1-6 was spread from several drivers at 
first so that the spread and answers received were 110, while the data that could be analyzed was 94 because the rest were not complete or filled by the same respondent.

\subsection{Operational Variable}

We adopted previous studies in measuring each research variable such as performance, discipline, motivation, training and incentives. Performance in this research is a condition where the taxi driver has a good performance on his job. Adopting Pawirosumanto et al. (2017), Groen et al. (2016), Salem and Abden (2017), Al-Belushi and Khan (2017), Kumara and Utama (2016), Sharma (2016), Hatane (2015), Kuzu and Ozilhan (2014), Khan et al. (2014), Baht (2013) the performance of the research was measured by 5 indicators, they are 1) Amount of delivery, 2) Minimization of cost, 3) Passenger comfort, 4) Score of Customer, and 5) Traffic Jump.

Discipline is a form of obedience to rules, adopted Pawirosumarto (2017) with a slight modification, in this study the discipline was measured using 3 indicators are 1) Presence, 2) Not be late, and 3) Not go home early.

Motivation in this research is something that comes from the driver who drives him to work, adopted the study of Al-Belushi and Khan (2017), Pawirosumarto et al. (2017), Nabi et al. (2017), and Khan et al. (2014) with modification, motivation in this study measured by 2 indicators are 1) comfortable in the future, and 2) Avoid in hard life.

Training in this research is an activity that is followed by drivers in learning and recognizing the driving process and good service at the beginning of joining as a driver or deepening and updating new sciences in the latest services and provisions. Adopting the research of Salem and Abdien (2017), Sharma (2016), Kumara and Utama (2016), Falola et al. (2014), Bhat (2013), training is measured using 2 indicators are 1) On the Job training and 2) On the schedule training.

Because the business unit of this research is taxi drivers who work with the commission system, the insetive research is all that is received by the driver in the form of money or other benefits. Adopting the research of AlBelushi and Khan (2017), Groen et al. (2016), Hamid et al. (2014), Hameed et al. (2014), incentives in this study were measured using 1) Commission, 2) Bonus, and 3) Health Insurance.

\subsection{Hypothesis Testing Method}

Structural Equation Model (SEM) approach used in this study by SmartPLS 3, goodness fit model analized by outer loading factor and AVE amount for validity and by Composite Reliability and Cronbach's alpha amount for reliability analysis and also adjust r-square. Inner model amount used for regression analysis this study.

\section{Result and Discussion}

4.1 Characteristic Respondent

94 drivers of taxi full fill the e-questionnaire and their profile are 1) all respondents is men, 2) driver with ages between 30 - 40 years old is highest while there a few drivers are older than 55 years old, and 3) Senior high school is highest of drivers' last education while there a few driver only was study in elementary school.

\subsection{Descriptive Analysis}

Table 1. Descriptive Statistics of Variables

\begin{tabular}{clrrrc}
\hline Rank & Variables & Min & Max & Mean & Std. Deviation \\
\hline 1 & MO & 1 & 6 & 5,7128 & 0,9548 \\
2 & PERF & 1 & 6 & 5,6862 & 0,9843 \\
3 & INC & 1 & 6 & 5,3865 & 1,3054 \\
4 & TR & 1 & 6 & 5,3245 & 1,3587 \\
5 & DI & 1 & 6 & 5,2447 & 1,5164 \\
\hline Note $P E R F \cdot$ Performance, DI: Discipline, MO : Motivation, TR: Training, INC: Incentive
\end{tabular}

With 1 for minimum amount and 6 for maximum amount of each variable, Table 1 explained that answer of respondent is variety, and that is good because perception of respondent is not uniform and variety. Amount mean of each variable is more than 5 of 6 , its explained that respondent have good perception for each indicator of variable. 


\subsection{Goodfit Analysis}

Table 2. Goodness of fit Analysis

\begin{tabular}{lcccccc}
\hline Variable & $\begin{array}{c}\text { Loading } \\
\text { Factor }\end{array}$ & AVE & $\begin{array}{c}\text { Validity Test } \\
\text { Result }\end{array}$ & $\begin{array}{c}\text { Composite } \\
\text { Reliability }\end{array}$ & $\begin{array}{c}\text { Croncbach's } \\
\text { Alpha }\end{array}$ & $\begin{array}{c}\text { Reliability Test } \\
\text { Result }\end{array}$ \\
\hline DI & $0,754-0,840$ & 0,651 & & 0,848 & 0,751 & \\
MO & $0,967-0,968$ & 0,936 & & 0,967 & 0,932 & Reliable \\
TR & $0,887-0,912$ & 0,839 & Valid & 0,894 & 0,765 & \\
INC & $0,835-0,929$ & 0,798 & & 0,922 & 0,873 & \\
PERF & $0,763-0,971$ & 0,839 & & 0,969 & 0,960 & \\
\hline
\end{tabular}

Note: PERF: Performance, DI: Discipline, MO: Motivation, TR: Training, INC: Incentive

On the table 2 looked that amounts of loading factor of each variable are more than 0,7 and mount VET is more than 0,5 so these resulted that data is valid. Amount of composite reliability and croncbach's alpha are more than 0,7 and these resulted that data is reliable. By validity test and reliability test explain that data and model of this study is good and can continue next analysis (Ghozali \& Latan, 2015; 76-77; Hair et al., 2012; Hair et al., 2011; Chin, 1998; Chin, 2010b).

\subsection{Hypothesis result}

Table 3. The Influence of Discipline, Motivation, Training and Incentive on Performance $\mathrm{PERF}=\mathrm{B} 0+\beta 1 \mathrm{DI}+\beta 2 \mathrm{MO}+\beta 3 \mathrm{TR}+\beta 4 \mathrm{INC}$

\begin{tabular}{lcrrr}
\hline \multicolumn{1}{c}{ Variables } & Prediction & Original estimate & t-statistics & P-Value \\
\hline DI & + & 0.207 & 2.045 & 0.041 \\
MO & + & 0.659 & 5.525 & 0.000 \\
TR & + & $-0,015$ & 0.140 & 0,889 \\
INC & + & 0,144 & 1.281 & 0.201 \\
\hline Adj. R ${ }^{2}$ & & 0.814 & & \\
Observation & & 94 & & \\
\hline
\end{tabular}

*** Significant at the $1 \%$ level, ** Significant at 5\% level, * Significant at $10 \%$ level

Note: PERF: Performance, DI: Discipline, MO: Motivation, TR: Training, INC: Incentive

Inner model in smartPLS3 used for regression test and hypothesis result. Table 3 explains that Discipline and Motivation have positive impact on Performance significantly while Training and Incentive are not, that is mean Hypothesis 1 and Hypothesis 2 are accepted while Hypothesis 3 and Hypothesis 4 are rejected.

\subsection{Discussion}

Results of Hypothesis 1 is Discipline has a positive impact on Performance significantly, these results explained that the driver have good discipline in the job time although in the present or service increase the performance. The result is consistent with prior research of Pawitosumarto et al. (2017).

Based on the results of the hypothesis 2 explained that Motivation has a positive impact on Performance significantly, these explained in line with motivation theory by Hezberg that the driver have a individual great motivation can support individual performance in the job. The results consistent with prior research of Al-Belushi and Khan (2017), Pawirosumarto et al. (2017), Nabi et al. (2017), and Khan et al. (2014)

Training has a negative impact on Performance not significantly based on result of Hypothesis 3 , these results confirm Aragon et al. (2014) but contrary with the research Salem and Abdien (2017), Sharma (2016), Kumara and Utama (2016), Falola et al. (2014), Bhat (2013). These result explained that the driver especially respondents in this study are not need training or maybe not like, because feel have a good skill in the driving although not training in the corporate.

On the results of hypothesis 4 describes Incentive have a positive impact on Performance not significantly, these result explain that for driver escpecially in the commission payment method are not motivated by incentive from corporate. These result is not consistent with research Al-Belushi and Khan (2017), Groen et al. (2016), Hamid et al. (2014), Hameed et al. (2014).

\section{Conclusions and Limitations}

Based on hypothesis result, some conclusion and limitation found for a simple explanation, as follows:

1. Discipline and Motivation as a part of internal factors of each driver found can increase performance of driver in the job. The information can used by corporate especially taxi corporation when recruitment of new driver for selected the driver who have good discipline and great motivation.

2. Training and Incentive as a part of corporate policy found not significantly impact for increasing performance. These can be information to corporate for explain the better system in according with employee and driver as the very important party in the company's revenue. 
3. The amount of samples in this study is small only 94 respondent and these not really sufficient to represent the population, higher amount of sample in the future is better.

\section{Acknowledgement}

This study is result of collaboration between Faculty of Economics and Business Universitas Mercu Buana and Universitas Trisakti, we are gratefull for the support of the Deans, Lecturer and Research Center at each university and especially blue bird's drivers as unit business in this study.

\section{References}

Al-Belushi, F.Y. and F.R. Khan. (2017). Impact of Monetary Incentives on Employee's Motivation: Shinas College of Technology, Oman - A Case Study. International Journal of Management, Innovation \& Entrepreneurial Research, Vol. 3, No 1

Aragon, M.I.B., D. Jimenez, and R.S. Valle. (2014). Training and performance: The mediating role organizational learning. Business Research Quarterly

Bhat, Z.H. (2013). Impact of Training on Employee Performance: A Study of Retail Banking Sector in India. Indian Journal of Applied Research, Vol. 3 Issue 6.

Chin, W. W. (1998). The Partial least squares approach for structuran equation modeling. In G.A. Marcoulides (Ed.), Modern methods for business research (pp. 295-236). London: Lawrence Erlbaum Associates.

Chin, W.W. (2010b). How to write up and report PLS analyses. In V.E. Vinzi, W.W. Chin, J. Henseler, \& H. Wang (Eds.), Handbook of partial leas squares: Concepts, methods and applications in marketing and related fields (pp. 83-97). Berlin: Springer.

Falola, H.O, A.O. Osibanjo and S.I.Jojo. (2014). Effectiveness of Training and Development on Employees' Performance and Organisation Competitiveness in the Nigerian Banking Industry. Economic Science Vol. 7 (56) No. 1

Gellert, F.J. and R. Schalk. (2012). The influence of age on perceptions of relationship quality and performance in care service works team. Employee Relations, Vol 34 No. 1

Gilbert, T.F. (1977). Training: The \$100 Billion Opportunity. Training and Development Journal.

Gilbert, T.F. and Gilbert, M.B. (1977). Knowledge Maps. Morristown: Praxis Technical Series.

Ghozali, I. and Latan, H. (2015). Partial Least Squares Konsep, Teknik dan Aplikasi Menggunakan Program SmartPLS 3.0 Untuk Penelitian Empiris. Semarang: Badan Penerbit Universitas Diponegoro.

Groen, B.A.C., M.J.F. Wouters and C.P.M. Wildrom. (2016). Employee participation, performance metrics, and job performance: a survey study based on self-determination theory. Management Accounting Research

Hair, J.F., C.M. Ringle, and M. Sarstedt. (2011). PLS-SEM: Indeed A Silver Bullet. Journal of Merketing Theory and Practice (19:2), pp 139-150

Hair, J.F., M. Sarstedt., C.M. Ringle, and J.A. Meda, (2012). An Assessment of the use of Partial Least Squares Structural Equation Modeling in Marketing Research. Journal of The Academy of Marketing Science (40:1), pp. 414-433

Hameed, A., M. Ramzan, H.M.K. Zubair, G. Ali and M. Arsian. (2014). Impact of Compensation on Employee Performance (Empirical Evidence from Banking Sector of Pakistan). International Journal of Business and Social Science, Vol. 5 No. 2

Hatane, S.E. (2015). Employee satisfaction and performance as intervening variables of learning organization on financial performance. Procedia - Social and Behavioral Sciences 211 (2015) 619-628

Hezberg, F. (1964). The Motivation-Hygiene Concept and Problems of Manpower. Personal Administrator (27), pp 3-7

Khan, I., H. Dongping and T. Ahmad. (2014). Impact of Attitude on Employee Performance: A Study of Textile Industry in Punjab, Pakistan. World Applied Sciences Journal Vol. 30

Kumara, I.W.S.E. and Utama, I.W.M. (2016). Pengaruh Pelatihan Terhadap Kinerja Karyawan Dengan Mediasi Kepemimpinan Pada Hotel Satriya Cottages Kuta-Bali. E-Jurnal Manajemen Unud, Vol. 5, No. 3, 1399-1428.

Mullen, J., E.K. Kelloway and M. Ted. (2017). Employer safety obligations, tranformatial leadership and their interactive effect on employee safety performance. Safety science, Vol. 91.

Nabi, M.N., M.M. Islam, T.M. Dip, M.A. Al Hossain. (2017). Impact of Motivation on Employee Performances: a case study of Karmasangsthan Bank Limited, Bangladesh. Arabian Journal of Business and Management Review 7:1

Pawirosumarto, S., P.K. Sarjana and M. Muchtar. (2017). Factors affecting employee performance of PT. Kiyokuni Indonesia. International Journal of Law and Management Vol. 59 No. 4

Rivai, V. and E.J. Sagala. (2009), Manajemen Sumber Daya Manusia untuk Perusahaan. Edisi Kedua,Raja Grafindo Persada, Jakarta.

Rotter, J.B. (1966). Genaralized Expectancies for Internal Versus External Control of Reinforcement. Phsycological Monographs, Vol. 80, pp 1-28. 
Salem, I.E and M.K. Abdien. (2017). Implementation of employee cross-crosstraing during perilous conditions in hotels. Tourism Management Perspective, Vol. 23

Sharma, S. (2016). Impact of Training on Employee Performance: Conceptual Study in Contect Motivation and Job Satisfaction in a Organization. International Journal of Emerging Research in Management \& Technology Vol 5. Issue 4

Triasmoko, D., M.D. Mukzam, and G.E. Nurtjahjono. (2014). Pengaruh Pelatihan Kerja Terhadap Kinerja Karyawan. Jurnal Administrasi Bisnis Vol. 12 No. 1.

Vosloban, R.I. (2012). The Influence of the employee performance on the company's growth - a managerial perspective. Procedia Economics and Finance, Vol. 3

Vrom, V.H. (1964). Work and Motivation, New York: Wiley, 331 p.

Wibowo. (2016). Manajemen Kinerja, Edisi Kelima. Rajawali Pers

www.bluebirdgroup.com 